\title{
PENGARUH PENAMBAHAN BERBAGAI AKTIVATOR DALAM PROSES PENGOMPOSAN SEKAM PADI (Oryza sativa)
}

\author{
Irvan, Permata Mhardela, Bambang Trisakti \\ Departemen Teknik Kimia, Fakultas Teknik, Universitas Sumatera Utara \\ Jl. Almamater Kampus USU, Medan 20155, Indonesia \\ Email :i_v_a_n_mz@yahoo.com
}

\begin{abstract}
Abstrak
Proses pengomposan sekam padi (oryza sativa) dengan menambahkan berbagai aktivator telah dilakukan di Pusdiklat LPPM, Universitas Sumatera Utara. Tujuan dari penelitian ini adalah untuk membandingkan pengaruh variasi pemberian slurry dan bakteri (ragi dan EM4) terhadap hasil pengomposan sekam padi. Adapun parameter yang diamati yaitu perubahan suhu, kandungan air, rasio $\mathrm{C} / \mathrm{N}$ dan perubahan $\mathrm{pH}$. Pada hasil akhir pengomposan menunjukkan bahwa dengan penambahan slurry, ragi dan EM4 dapat menurunkan suhu dan rasio $\mathrm{C} / \mathrm{N}$, dan dengan penambahan ragi dan 2 liter slurry dapat mempercepat proses dekomposisi kompos.
\end{abstract}

Kata kunci: sekam padi, pengomposan, EM4, slurry

\begin{abstract}
Composting process of rice husk (Oryza sativa) by adding various activators have been carried out in LPPM Training Center, University of Sumatera Utara. The purpose of this study was to compare the effect of variation of slurry and bacteria (yeast and EM4) on rice husk composting results. The parameters observed were changes in temperature, water content, $\mathrm{C} / \mathrm{N}$ ratio, and $\mathrm{pH}$. At the end of the composting results showed that the addition of slurry, yeast and EM4 can lower the temperature and $C / N$ ratio, and with the addition of yeast and 2 liters of slurry can speed up the process of decomposition of compost.
\end{abstract}

Keywords : rice hulk, composting, EM4, slurry

\section{Pendahuluan}

Sekam padi dikategorikan sebagai biomassa yang dapat digunakan untuk berbagai kebutuhan seperti bahan baku industri, pakan ternak dan energi atau bahan bakar. Selama ini, sekam padi merupakan bahan buangan yang biasanya hanya dibakar. Namun praktek semacam ini menyebabkan timbulnya persoalan pencemaran udara [1].

Peningkatan produksi komoditas padi setiap tahunnya secara langsung meningkatkan jumlah sekam padi. Pada tahun 2008 produktivitas padi mencapai 60.279.897 ton. Dengan demikian produksi sekam padi sebesar 20-30\% dari proses penggilingan padi dapat mencapai 12.055.979 hingga 18.083.969 ton [4]. Sekam padi dengan jumlah yang besar tersebut dapat menimbulkan pencemaran lingkungan.

Salah satu upaya untuk membantu mengatasi permasalahan limbah pertanian adalah melakukan upaya daur ulang dengan penekanan pada proses pengomposan. Kelebihan lain dari pengolahan limbah menjadi kompos adalah aman bagi produk dan lahan pertanian, kompos dapat dibuat sendiri oleh masyarakarat luas dengan bahan baku yang cukup sederhana dan mudah dijumpai serta proses pembuatannya yang tidak terlalu rumit [13].

Berbagai upaya dapat dilakukan untuk mempercepat proses pengomposan dengan melakukan berbagai perlakuan dalam pengomposan yaitu penambahan slurry, pembalikan dan penambahan aktivator dengan mikroorganisme yang berbeda sehingga dapat dilihat perbandingan dari kualitas kompos yang dihasilkan [6].

Permasalahan pokok yang akan dijawab dalam penelitian ini adalah mampukah aktivator yang digunakan (slurry, ragi dan EM4) mempercepat proses pematangan kompos dari sekam padi.

\section{Teori}

Kompos adalah hasil penguraian parsial/tidak lengkap dari campuran bahan-bahan organik. Pengomposan adalah proses dimana bahan organik mengalami penguraian secara biologis, khususnya oleh mikroba-mikroba yang memanfaatkan bahan organik sebagai sumber energi [5].

Proses pengomposan tergantung pada :

a. Karakteristik bahan yang dikomposkan

b. Aktivator pengomposan yang dipergunakan

c. Metode pengomposan yang dilakukan [7]

Slurry adalah residu dari input yang keluar dari lubang pengeluaran setelah mengalami proses fermentasi oleh bakteri metana dalam kondisi anaerobik di dalam digester pada proses pembuatan biogas dari limbah bahan organik. Bahan organik dikonversi menjadi biogas $50-60 \%$, yang tersisa adalah lumpur. Slurry mengalami penurunan COD sebesar 90\% dari kondisi bahan awal dan perbandingan BOD/COD Slurry sebesar 0,37. Nilai ini lebih kecil dari perbandingan BOD/COD limbah cair sebesar 0,5 . Slurry juga mengandung lebih sedikit 
bakteri pathogen sehingga aman untuk digunakan sebagai pupuk [13].

Proses pengomposan ala keranjang Takakura merupakan proses pengomposan aerob, dimana udara dibutuhkan sebagai asupan penting dalam proses pertumbuhan mikroorganisme yang menguraikan sampah menjadi kompos. Media yang dibutuhkan dalam proses pengomposan yaitu dengan menggunakan keranjang berlubang. Proses pengomposan metode ini dilakukan dengan cara memasukkan sampah organik idealnya sampah organik tercacah ke dalam keranjang setiap harinya dan kemudian dilakukan kontrol suhu dengan cara pengadukan dan penyiraman air [10].

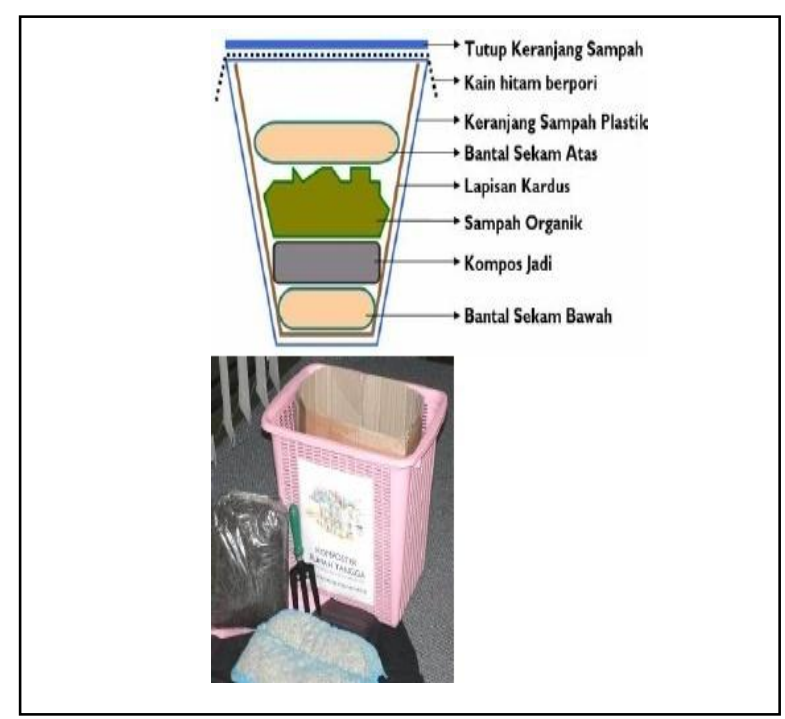

Gambar 1. Keranjang Takakura [3].

Enzim maupun mikroorganisme tertentu dapat ditambahkan sebagai aktivator pada proses pengomposan. Mikroorganisme yang dapat digunakan pun beragam sehingga diperlukan mikroorganisme yang tepat terhadap proses pengomposan sehingga karakteristik kompos yang dihasilkan pun memiliki kualitas yang baik [7].

\section{Metodologi Penelitian}

Bahan yang digunakan adalah sekam padi, slurry, EM4 dan ragi serta bahan untuk analisa kompos meliputi larutan $\mathrm{K}_{2} \mathrm{Cr}_{2} \mathrm{O}_{7} \quad 0,1 \mathrm{~N} ; \mathrm{H}_{2} \mathrm{SO}_{4(\mathrm{p})} ; \mathrm{H}_{3} \mathrm{PO}_{4}$ $85 \%$; $\mathrm{NaF} 4 \%$; larutan $\mathrm{Fe}\left(\mathrm{NH}_{4}\right)_{2}\left(\mathrm{SO}_{4}\right)_{2} 0,5 \mathrm{~N}$; $\mathrm{C}_{6} \mathrm{H}_{4} \mathrm{OHCOOH}$.

Variabel-variabel dalam penelitian ini adalah variabel tetap yaitu jumlah sekam padi dan variabel bebas yaitu volume slurry dan aktivator (ragi dan EM4). Parameter yang diamati dan dianalisa pada penelitian ini antara lain temperatur, kadar air, ratio $\mathrm{C} / \mathrm{N}$ dan $\mathrm{pH}$ kompos. Penelitian dilakukan selama 60 hari di Pusdiklat LPPM. Pengukuran temperatur kompos dilakukan setiap hari, kemudian dilakukan pembalikan bahan kompos. Pembalikan dilakukan 2 kali dalam sehari.
Penelitian ini menggunakan keranjang Takakura sebanyak 5 buah, dan dilakukan berbagai perlakuan seperti yang diperlihatkan pada Tabel 1 .

Tabel 1. Perlakuan penelitian berdasarkan penambahan slurry dan aktivator (ragi dan EM4) pada berbagai volume selama proses pengomposan

\begin{tabular}{|c|c|c|c|}
\hline Perlakuan & $\begin{array}{c}\text { Volume } \\
\text { slurry } \\
\text { (Liter) }\end{array}$ & $\begin{array}{c}\text { Vol. Aktivator } \\
\text { (Liter) }\end{array}$ & $\begin{array}{c}\text { Waktu } \\
\text { penambahan }\end{array}$ \\
\hline 1 & 1 & - & $\begin{array}{c}\text { Setiap 3 hari } \\
\text { sekali }\end{array}$ \\
\hline 2 & 1,5 & - & $\begin{array}{c}\text { Setiap 3 hari } \\
\text { sekali }\end{array}$ \\
\hline 3 & 2 & - & $\begin{array}{c}\text { Setiap 3 hari } \\
\text { sekali }\end{array}$ \\
\hline 4 & - & 3 (ragi+EM4) & $\begin{array}{c}\text { Di awal } \\
\text { pengomposan } \\
\text { Di awal } \\
\text { pengomposan }\end{array}$ \\
\hline 5 & - & 3 (ragi) & \\
\hline
\end{tabular}

\section{Hasil dan Pembahasan}

a. Penambahan Slurry pada Berbagai Volume Selama Proses Pengomposan

Selama proses pengomposan dilakukan pembalikan 2 kali sehari dan penambahan kompos halus sebanyak $1 \mathrm{~kg}$ untuk masing-masing keranjang.

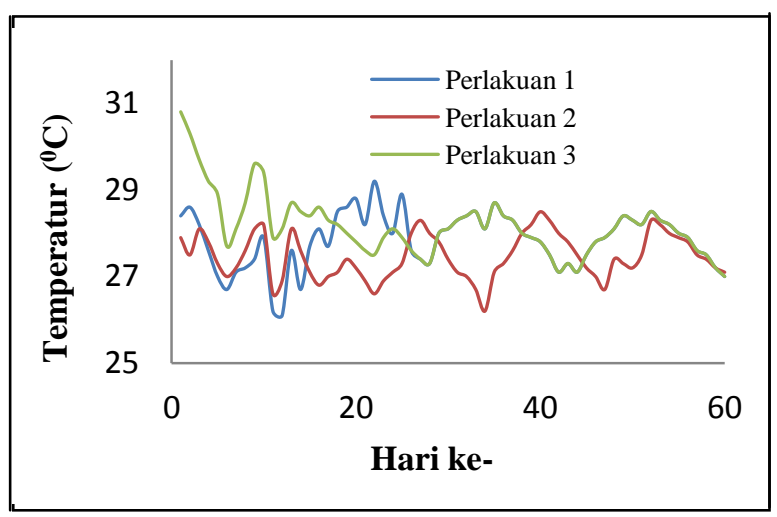

Gambar 2. Pengaruh Penambahan Volume Slurry Selama Proses Pengomposan terhadap Suhu

Gambar 2 memperlihatkan bahwa suhu maksimum yang dapat dicapai untuk tumpukan kompos di keranjang 1adalah $29,2{ }^{\circ} \mathrm{C}$, keranjang 2 adalah $28,5^{\circ} \mathrm{C}$ sedangkan pada keranjang 3 adalah $30,8^{\circ} \mathrm{C}$. Pada penelitian ini, volume slurry yang ditambahkan tidak menunjukkan perbedaan yang nyata pada temperatur. Adapun warna yang ditunjukkan pada akhir pengomposan pada pengamatan visual, bukanlah menunjukkan tejadinya penguraian, namun berasal dari warna pekat slurry.

Selain itu Gambar 2 menunjukkan bahwa suhu mengalami fluktuasi. Menurut teori, kisaran temperatur yang menunjukkan aktivitas pengomposan yang baik yaitu antara $30-60^{\circ} \mathrm{C}$, oleh sebab itu dapat 
dilihat bahwa hasil yang diperoleh tidak menunjukkan terjadinya proses pengomposan yang baik [12].

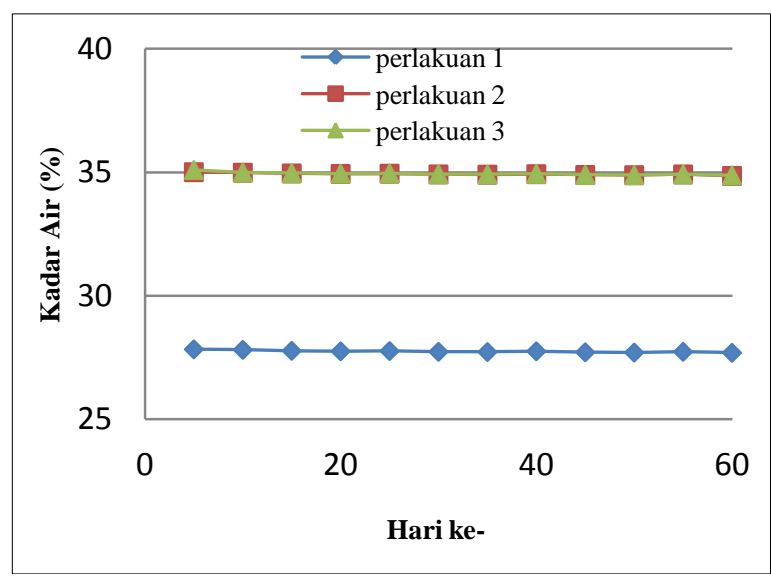

Gambar 3. Pengaruh Penambahan Volume Slurry Selama Proses Pengomposan terhadap Kadar Air

Gambar 3 memperlihatkan nilai kadar air yang diperoleh tidak mengalami perubahan yang cukup signifikan. Berdasarkan volume slurry yang digunakan, dimana kadar air untuk tiap variasi kompos berkisar antara 27,7-35,1\%. Nilai kadar air tersebut sesuai dengan kadar air dalam SNI 19-70302004 [2] yaitu kurang dari 50\%. Kadar air terendah terdapat pada keranjang 1 sebesar $27,7 \%$ dan tertinggi pada variasi keranjang 3 yaitu sebesar $35,1 \%$.

Gambar 3 menunjukkan bahwa semakin banyak volume slurry yang ditambahkan maka semakin besar kadar air yang diperoleh. Sehingga timbunan bahan yang dikomposkan perlu dijaga kelembabannya karena bila kelebihan air akan mengakibatkan volume udara jadi berkurang. Semakin basah timbunan tersebut maka harus semakin sering diaduk untuk menjaga dan mencegah pembiakan bakteri anaerobik yang akan menghasilkan senyawa-senyawa yang berbau tidak sedap seperti asam-asam organik, amonia dan $\mathrm{H}_{2} \mathrm{~S}$ [8].

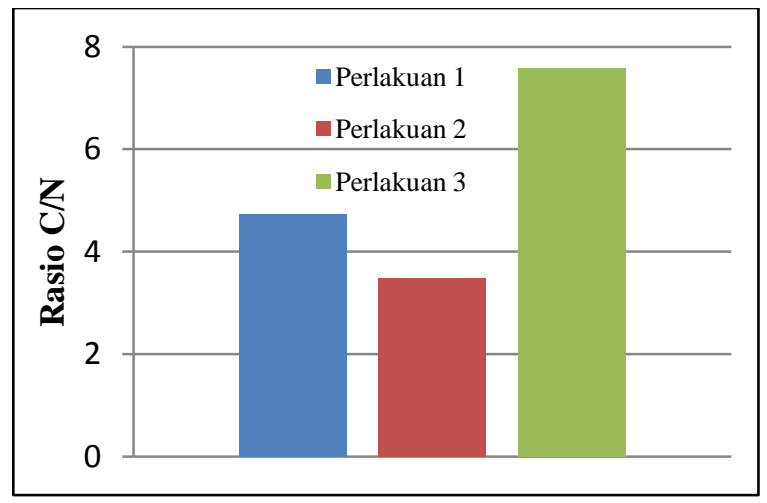

Gambar 4. Pengaruh Penambahan Volume Slurry Selama Proses Pengomposan terhadap Rasio C/N

Dari Gambar 4 memperlihatkan pengaruh penambahan volume slurry selama proses pengomposan terhadap rasio $\mathrm{C} / \mathrm{N}$ tertinggi terdapat pada keranjang 3 dengan nilai 7,58 dan terendah pada keranjang 2 yaitu 3,48 . Nilai tersebut lebih kecil dari 10. Nilai $\mathrm{C} / \mathrm{N}$ tersebut tidak sesuai dengan rasio $\mathrm{C} / \mathrm{N}$ dalam SNI 19-7030-2004 yaitu antara 10-20 [2]. Gambar 4 juga menunjukkan penurunan nilai $\mathrm{C} / \mathrm{N}$ bahan akibat dari semakin meningkatnya aktivitas mikroorganisme yang melakukan proses perombakan bahan organik. Timbunan yang bernitrogen terlalu sedikit (zat yang dibutuhkan mikroorganisme penghancur untuk tumbuh dan berbiak) sehingga tidak akan menghasilkan panas untuk membusukkan material dengan cepat [8].

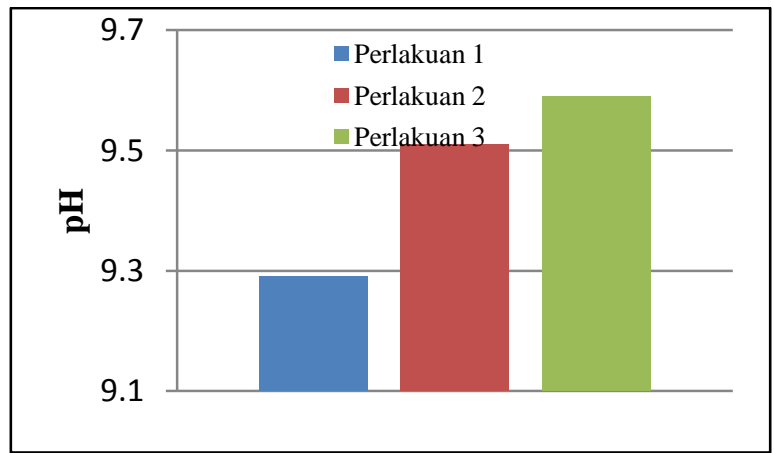

Gambar 5. Pengaruh Penambahan Volume Slurry Selama Proses Pengomposan terhadap pH

Gambar 5 memperlihatkan bahwa pada keranjang 1, 2 dan 3 dilakukan penambahan slurry setiap 3 hari sekali dan dapat dilihat dimana terjadi peningkatan $\mathrm{pH}$ pengomposan. Pada perlakuan 1 diperoleh $\mathrm{pH}$ sebesar 9,29, perlakuan 2 diperoleh $\mathrm{pH}$ 9,51 dan perlakuan 3 dengan $\mathrm{pH}$ 9,59 sehingga keadaan kompos berubah menjadi basa. Nilai kisaran $\mathrm{pH}$ yang diperoleh tidak sesuai dengan dengan SNI 19-7030-2004 [2]. Pada Gambar 5 diperoleh pH dalam kondisi basa, hal ini disebabkan asam-asam organik sederhana yang terbentuk pada dekomposisi awal tadi dikonversi menjadi metan dan $\mathrm{CO}_{2}$ oleh bakteri pembentuk metan [9].

b. Perbandingan Antara Pemberian Ragi dan Tanpa Ragi (Menggunakan EM4)

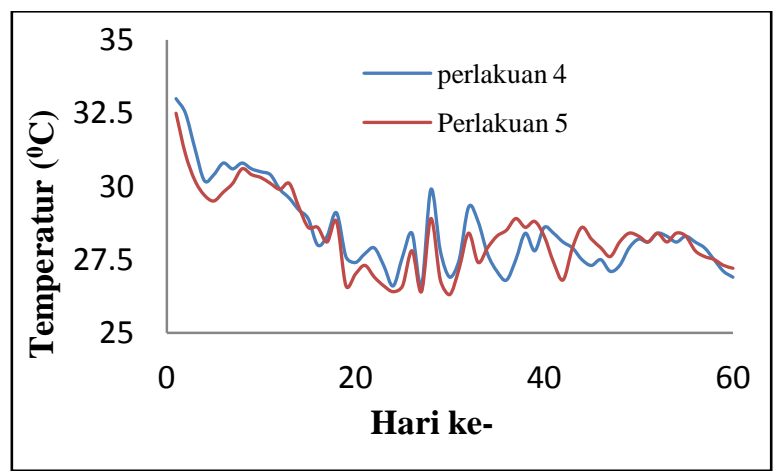

Gambar 6. Pengaruh Perbandingan Pemberian Ragi dan Tanpa Ragi (Menggunakan EM4) terhadap Suhu 
Gambar 6 memperlihatkan fluktuasi suhu selama proses pengomposan. Pada gambar dapat dilihat temperatur maksimum yang dapat dicapai kompos pada keranjang 4 adalah $33,4^{\circ} \mathrm{C}$ dan untuk keranjang 5 adalah $32,8{ }^{0} \mathrm{C}$. Menurut teori, kisaran temperatur yang menunjukkan aktivitas pengomposan yang baik yaitu antara $30-60^{\circ} \mathrm{C}$ [12]. Pada penelitian ini pemberian dan tanpa pemberian ragi tidak memberikan pengaruh yang nyata terhadap temperatur. Oleh sebab itu dapat disimpulkan bahwa hasil yang diperoleh belum menunjukkan terjadinya proses pengomposan yang baik.

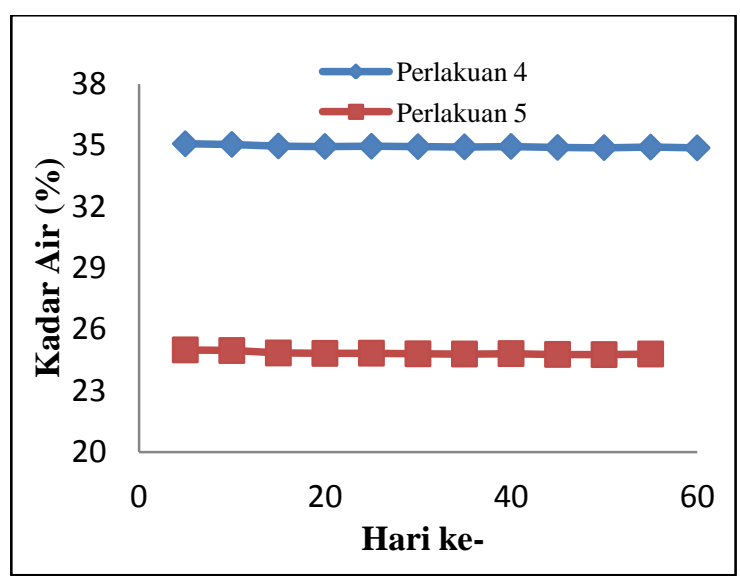

Gambar 7. Pengaruh Perbandingan Pemberian Ragi dan Tanpa Ragi (Menggunakan EM4) terhadap Kadar Air

Gambar 7 memperlihatkan bahwa nilai kadar air yang diperoleh tidak mengalami perubahan yang signifikan, dimana dari gambar di atas dapat dilihat bahwa kadar air terendah diperoleh pada keranjang 5 yaitu sekitar $24,5 \%$ dan nilai kadar air tertinggi diperoleh pada keranjang 4 yaitu dengan nilai 35,08\%. Nilai kadar air tersebut sesuai dengan teori yaitu kurang dari $50 \%$ [2].

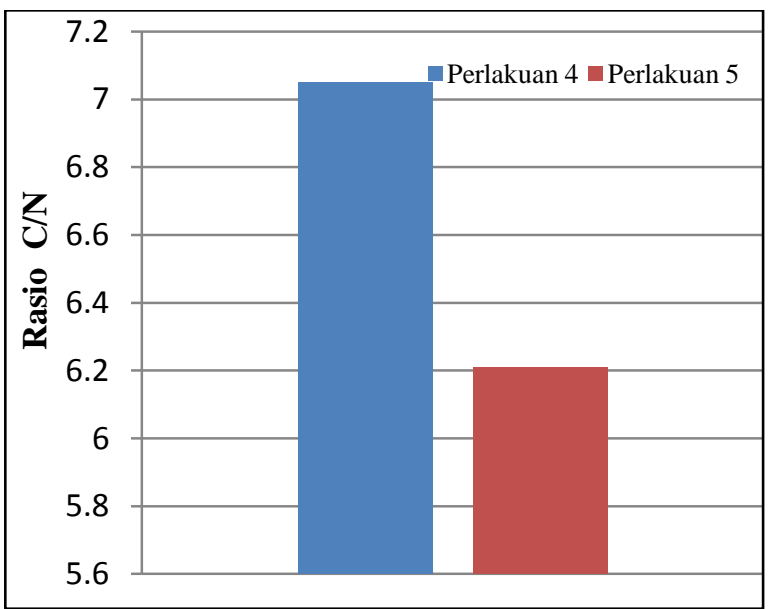

Gambar 8. Pengaruh Perbandingan Pemberian Ragi dan Tanpa Ragi (Menggunakan EM4) terhadap Rasio $\mathbf{C} / \mathbf{N}$
Gambar 8 memperlihatkan bahwa nilai rasio $\mathrm{C} / \mathrm{N}$ yang diperoleh mengalami penurunan dengan pemberian ragi, dimana dari gambar diatas dapat dilihat bahwa rasio $\mathrm{C} / \mathrm{N}$ terendah diperoleh pada keranjang 5 yaitu sekitar 6,21 dan nilai kadar air tertinggi diperoleh pada keranjang 4 yaitu sekitar 7,05. Nilai $\mathrm{C} / \mathrm{N}$ tersebut tidak sesuai dengan rasio $\mathrm{C} / \mathrm{N}$ dalam SNI 19-7030-2004 yaitu antara 10-20 [2].

Penurunan rasio $\mathrm{C} / \mathrm{N}$ dapat terjadi karena proses perubahan pada nitrogen dan karbon selama proses pengomposan. Perubahan kadar nitrogen menurut teori dikarenakan pada proses terjadi penguraian senyawa organik kompleks menjadi asam organik sederhana yang dilanjutkan dengan penguraian bahan organik yang mengandung nitrogen [9].

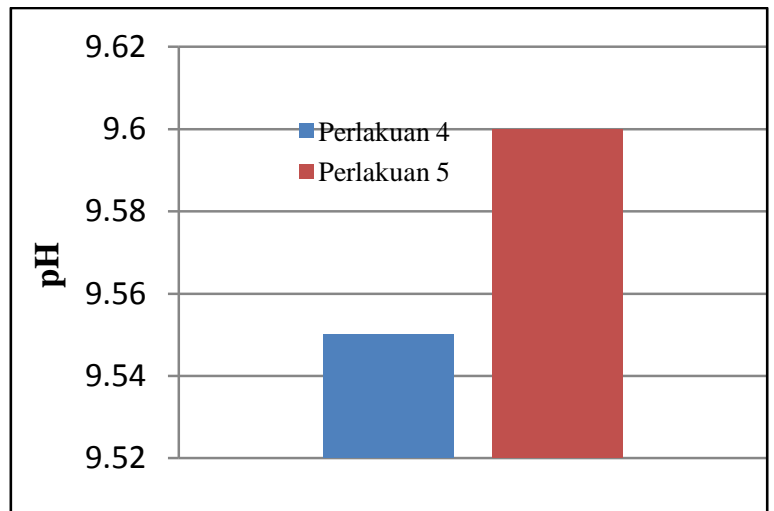

Gambar 9. Pengaruh Perbandingan Pemberian Ragi dan Tanpa Ragi (Menggunakan EM4) terhadap pH

Gambar 9 memperlihatkan bahwa nilai $\mathrm{pH}$ tertinggi terdapat pada keranjang 5 yaitu 9,6 dan nilai $\mathrm{pH}$ terendah terdapat pada keranjang 4 yaitu dengan nilai 9,55. Untuk mencapai dekomposisi secara aerobik yang optimal pada proses pengomposan maka $\mathrm{pH}$ yang dibutuhkan adalah 7- 7,5 [11]. Rentang maksimum pH untuk kebanyakan bakteri adalah 6-7,5. Sedangkan untuk jamur 5-8. Berdasarkan uraian tersebut maka kondisi optimum $\mathrm{pH}$ adalah 7 atau mulai dari 5 sampai 8 [12]. Oleh sebab itu pH yang diperoleh pada akhir pengomposan tidaklah menunjukkan bahwa pengomposan berjalan dengan baik.

\section{Kesimpulan}

Berdasarkan hasil penelitian diperoleh bahwa konsidi kompos yang hampir memenuhi kualitas kompos berdasarkan SNI 19-7030-2004 yaitu terdapat pada perlakuan 3 , dimana suhu maksimum yang diperoleh yaitu $32,8^{\circ} \mathrm{C}$, kadar air $35,1 \%$, rasio $\mathrm{C} / \mathrm{N}$ 7,58 dan $\mathrm{pH}$ 9,59. Penelitian juga menyimpulkan bahwa semakin besar volume slurry yang digunakan maka semakin besar pula $\mathrm{pH}$ yang diperoleh. Berdasarkan hasil di atas disimpulkan bahwa penambahan slurry dari fermentor biogas pada sekam padi dapat mempercepat pematangan kompos sehingga kompos lebih mudah terurai atau terdekomposisi. 


\section{Daftar Pustaka}

[1] Badan Penelitian dan Pengembangan Pertanian, Sekam Padi sebagai Sumber Energi Alternatif dalam Rumah Tangga Petani, http://www.bps.go.id/sector/agri/pangan/table.1. shtml, 2008, diakses pada 11 Agustus 2013.

[2] Badan Standarisasi Nasional (BSN), Spesifikasi Kompos dari Sampah Organik Domestik, SNI 19-7030-2004.

[3] Bapelkes, Pembuatan Kompos dengan Metode Takakura, http://bapelkescikarang.or.id/bapelkescikarang/i mages/stories/KurmodTTG/pengelolaansampah/ modul/modulpembuatankomposmetodetakakura. pdf, diakses pada 16 juli 2013.

[4] Biro Pusat Statistik, Area Produksi, Produktivitas, dan Produksi Padi di Indonesia, http://www.bps.go.id/sector/agri/pangan/table.1. shtml, 2008, diakses pada 11 Agustus 2013.

[5] Crawford. J.H, Composting of Agricultural Waste, in Biotechnology Applications and Research, Paul N, Cheremisinoff and R. P.Ouellette (ed), 2003, p. 68-77.

[6] Fitrah Mulyana, Perbedaan Kualitas Sampah Organik Menggunakan Sekam Padi (Oryza sativa) Anatara Penambahan Orgadec dengan EM4, Jurnal Makara Sains Vol 14 No. 1, Jakarta, 2009.

[7] Isroi, Pengomposan Limbah Padat Organik, http://www.ipard.com/art_perkebun/KomposLim bahPadatOrganik.pdf, diakses pada 16 Juli 2013.

[8] Murbandono, H. S, Membuat Kompos, Penebar Swadaya, Jakarta, 1997.

[9] Polprasert. Chongkrak, Organik Waste Management: Technology and Management, John Willey Sons, Chichester, Inggris, 1996.

[10] Pusat Pemberdayaan Komunitas Perkotaan 2007, Membuat Keranjang Takakura Sendiri, Universitas Surabaya,

http://keranjangtakakura.blogspot.com, diakses pada 16 Juli 2013.

[11] Tchobanoglous. G, Theisen.H, and Vigil. S.H, Integrated Solid Waste Management: Engineering Principles and Management Issues, International Edition, Mc Graw Hill, New Tork, 1993.

[12] Wahyono. Sri, Sahwan. L Firman, Suryanto. Freddy, Mengolah Sampah Menjadi Kompos, Pusat Pengkajian dan Penerapan Teknologi Lingkungan BPPT, Jakarta, 2003.

[13] Widodo, dkk, Pemanfaatan Limbah Industri Organik Pertanian Untuk Energi Biogas, Prosiding Konferensi Nasional 2007: Pemanfaatan Hasil Samping Industri Etanol Serta Peluang Pengembangan Industri Integratednya, Jakarta, 2007. 